\title{
ARSITEKTUR PERKEBUNAN VERTIKAL SEBAGAI SOLUSI DARI PERMASALAHAN PANGAN DAERAH PERKOTAAN
}

\author{
Alexander Yusuf Yogie ${ }^{1)}$ \\ 1)Program Studi S1 Arsitektur, Fakultas Teknik, Universitas Tarumanagara, alexanderyogie87@gmail.com
}

\begin{abstract}
ABSTRAK
Seiring pertumbuhan penduduk yang terus meningkat dari waktu ke waktu membuat ekologi yang ada menjadi tidak seimbang yang disebabkan oleh eksploitasi manusia terhadap sumberdaya yang ada. Arsitektur yang hadir dalam bentuk bangunan atau ruang yang dirancang untuk mewadahi kegiatan beraktivitas manusia turut menjadi alasan kerusakan ekologi yang ada di bumi ini. Arsitektur yang memiliki keberpihakan terhadap ekologi sangat dibutuhkan untuk menghambat atau bahkan mencegah kehancuran alam yang berakibat akan punahnya kehidupan di dunia ini. Teknologi yang maju diharapkan dapat bersinergi dengan arsitektur. Kebutuhan pangan yang tinggi di daerah perkotaan serta minimnya lahan produktif penghasil pangan akan menjadi bom waktu yang dapat memperburuk situasi di muka bumi ini. Tanah dan air yang terus dieksploitasi untuk menghasilkan makanan untuk manusia, serta jejak karbon yang terus dihasilkan dari proses produksi hingga distribusi kebutuhan pangan manusia di perkotaan. Tema melampaui ekologi (Beyond Ecology) ini diharapkan bisa menjadi dasar dalam mengatasi permasalahan kebutuhan pangan di kota besar yang memiliki minim lahan produktif. Dengan teknologi, dan keberpihakan perancang terhadap keberlangsungan ekologi dapat berdampak pada ketahanan pangan serta menurunnya jejak karbon hasil dari distribusi dan produksi kebutuhan pangan di masa depan.
\end{abstract}

Kata kunci: Jejak Karbon; Masa depan; Pangan; Perkebunan Vertikal; Pertumbuhan Penduduk.

\begin{abstract}
As population growth continues to increase from time to time, the existing ecology becomes unbalanced caused by human exploitation of existing resources. Architecture that is present in the form of buildings or spaces designed to accommodate human activities is also the reason for the ecological damage that exists on this earth. Architecture that is in favor of ecology is needed to inhibit or even prevent the destruction of nature which will result in the extinction of life in this world. Advanced technology is expected to synergize with architecture. The high demand for food in urban areas and the lack of productive land for food production will become a ticking time bomb that can worsen the situation on earth. Land and water that continue to be exploited to produce food for humans, as well as the carbon footprint that continues to be generated from the production process to the distribution of human food needs in urban areas. The theme beyond ecology (Beyond Ecology) is expected to be the basis for overcoming the problem of food needs in big cities that have minimal productive land. With technology, and the designer's alignment with ecological sustainability can have an impact on food security and reduce the carbon footprint resulting from the distribution and production of food needs in the future.
\end{abstract}

Keywords: Carbon Footprint; Food; Future; Population Growth; Vertical Farming. 


\section{PENDAHULUAN}

\section{Latar Belakang}

Seiring bertumbuhnya sebuah kota, yang mempengaruhi banyak aspek, mulai dari pertumbuhan jumlah penduduk, keterbatasan lahan, hingga berujung dengan potensi munculnya krisis pangan di area perkotaan. Di kota-kota besar yang kini semakin berkurang lahan produktif untuk memenuhi kebutuhan pangan daerahnya sendiri. Seperti Jakarta yang kebutuhan pangannya terus dipasok oleh daerah lain bahkan pulau lain. Tanpa disadari selain kerusakan ekosistem tanah dan air yang terus dipaksakan untuk menghasilkan kebutuhan pangan, pendistribusian yang jauh juga turut memberikan efek negatif bagi lingkungan, yaitu jejak karbon yang dihasilkan dari kendaraan-kendaraan besar yang digunakan untuk mengantarkan pasokan makanan dari daerah penghasil ke daerah yang mengkonsumsi. Melihat prediksi di tahun 2050 bahwa hampir 68\% penduduk akan tinggal di kota, yang pasti akan menambah beban kota untuk menyediakan kebutuhan pangan bagi setiap penduduknya. Jika tidak mulai berbenah untuk meningkatkan produktivitas penghasilan pangannya, Jakarta dapat menjadi kota yang terus sangat bergantung pada daerah lain dari segi kebutuhan pangan. Yang disaat bersamaan akan terus membuat kerusakan lingkungan terus meningkat karena lahan-lahan di daerah yang terus dipaksakan untuk terus menghasilkan makanan, serta polusi yang akan terus bertambah seiring semakin banyaknya pengiriman kebutuhan pangan dari daerah ke Jakarta. Program perkebunan vertikal akan menjadi perubah nasib masa depan perkotaan menjadi lebih baik. Dimana perkebunan vertikal ini mampu dengan mandiri memenuhi kebutuhan pangan di perkotaan yang akan berdampak langsung pada pemenuhan pangan masyarakat kota, serta menghasilkan penelitian yang lebih mendalam mengenai pertanian yang berkelanjutan. Dengan semua hal di atas, daerah perkotaan akan terselamatkan dari masalah pangan yang telah berlarut-larut.

\section{Rumusan Masalah}

Bagaimana membentuk sebuah arsitektur yang memiliki tingkat produksi agrikultur yang maksimal bagi masyarakat Jakarta?; Program apa yang dapat memberikan dampak signifikan dari segi kebutuhan pangan dan pencemaran udara di kota Jakarta?; Bagaimana cara menghasilkan energi yang berkelanjutan untuk memenuhi kebutuhan energi untuk operasional Vertical Farming?

\section{Tujuan}

Tujuan dari proyek ini adalah untuk mempersingkat proses distribusi pangan serta meningkatkan ketahanan pangan kota DKI Jakarta melalui program dari proyek yang dirancang ini akan mengacu pada agenda dunia yang tercantum pada Sustainable Development Goals untuk mencapai masa depan yang berkelanjutan meliputi beberapa goal ini:

Goal 3 - Good Health and Well Being

Ensure health lives and promote well-being for all at all ages: kesehatan secara fisik adalah salah satu cara untuk meningkatkan kualitas hidup dari manusia. Memakan makanan yang dihasilkan dengan minim proses kimia dan lebih segar tentu saja dapat meningkatkan kualitas hidup dari masyarakat.

\section{Goal 7 - Affordable and Clean Energy}

Ensure access to affordable, reliable, sustainable and modern energy for all: dengan teknologi yang akan semakin maju. Bercocok tanam akan menggunakan energi yang terbaharukan dan jauh lebih ramah terhadap lingkungan, karena proses bercocok tanam yang tidak lagi memanfaatkan sebidang tanah yang akan terkena kimia dari proses penumbuhan kebutuhan pangan. 
Goal 9 - Industry, Innovation, and Infrastructure

Build resilient infrastructure, promote inclusive and sustainable industrialization and foster innovation: dengan Teknologi yang terus berinovasi, industri agrikultur di perkotaan dapat menjadi banyak solusi dari segala permasalahan yang ada, mulai dari kebutuhan pangan itu sendiri, hingga isu lingkungan yang ada. Industri agrikultur akan lebih produktif dan terus berinovasi.

Goal 11 - Sustainable Cities and Communities

Make cities and human settlements inclusive, safe, resilient and sustainable: kota yang memiliki ketahanan pangan serta masyarakat yang sadar akan pentingnya ketahanan pangan akan membuat kota menjadi tempat yang sedikit lebih baik daripada sebelumnya. Dimana kebutuhan pokok dapat terpenuhi dengan mudah dan sehat.

\section{Goal 12 - Responsible Consumption and Production}

Ensure sustainable consumption and production patterns: dengan hadirnya Vertical Farming ini akan menghasilkan proses produksi kebutuhan pangan secara berkelanjutan, stabil dan ramah lingkungan. Serta memberikan produk yang lebih segar dan sehat kepada konsumen langsung.

\section{KAJIAN LITERATUR}

\section{Arsitektur Ekologi}

Ekologi berasal dari bahasa Yunani 'oikos' dan 'logos'. Oikos berarti rumah tangga atau cara bertempat tinggal, dan logos berarti ilmu atau bersifat ilmiah. Ekologi didefinisikan sebagai ilmu yang mempelajari tentang hubungan timbal balik antara makhluk hidup dengan lingkungan di sekitarnya. Arsitektur berkelanjutan yang ekologis dapat dikenali dengan cara seperti tidak menghabiskan bahan lebih cepat daripada tumbuhnya kembali bahan tersebut oleh alam; menggunakan energi terbarukan secara optimal; menghasilkan sampah yang dapat dimanfaatkan sebagai sumber bahan baru. Arsitektur ekologis menggambarkan bahwa terdapat perhatian kepada lingkungan alam dan sumber alam yang terbatas. Secara umum, arsitektur ekologis dapat diartikan sebagai penciptaan lingkungan yang lebih sedikit mengkonsumsi dan lebih jauh lebih banyak menghasilkan kekayaan alam. Arsitektur tidak dapat menghindari dari sebuah tindakan perusakan lingkungan. Namun, arsitektur ekologis dapat digambarkan sebagai arsitektur yang hendak merusak lingkungan seminimal mungkin. Untuk mencapai kondisi tersebut, desain diolah dengan cara memperhatikan aspek iklim, rantai bahan, dan masa pakai material bangunan. Prinsip utama arsitektur ekologis menghasilkan keselarasan antara manusia dengan lingkungan alamnya.

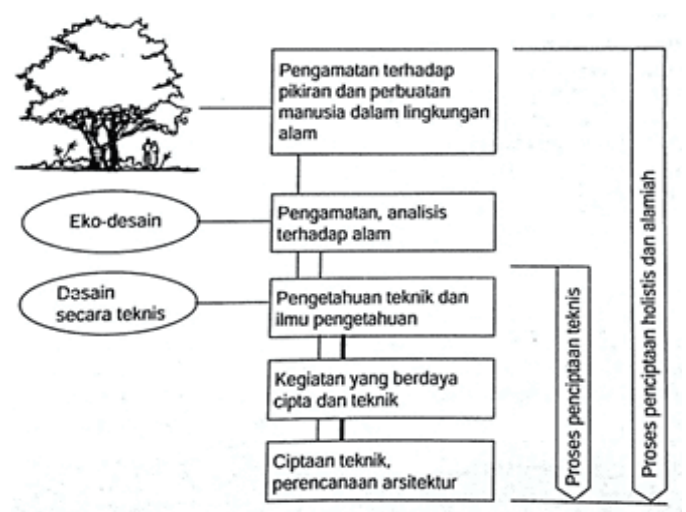

Diagram 1 . Pola Pikir Desain Arsitektur Ekologis Sumber: Frick, H., 2007 
Arsitektur ekologis menekankan pada konsep ekosistem, yaitu komponen lingkungan hidup harus dilihat secara terpadu sebagai komponen yang berkaitan dan saling bergantung antara satu dengan yang lainnya dalam suatu sistem. Cara ini dikenal dengan pendekatan ekosistem atau pendekatan holistik. Dalam ekosistem terjadi peredaran, yaitu suatu kondisi peralihan dari keadaan satu ke keadaan lainnya secara berulang-ulang yang seakan-akan berbentuk suatu lingkaran. Namun demikian, peredaran tersebut bersifat linier atau dengan kata lain tidak dapat diputar secara terbalik. Ekosistem terdiri dari makhluk hidup (komunitas biotik) dan lingkungan abiotik. Kedua unsur tersebut masing-masing memiliki pengaruh antara satu dengan lainnya untuk memelihara kehidupan sehingga terjadi suatu keseimbangan, keselarasan, dan keserasian alam di bumi.

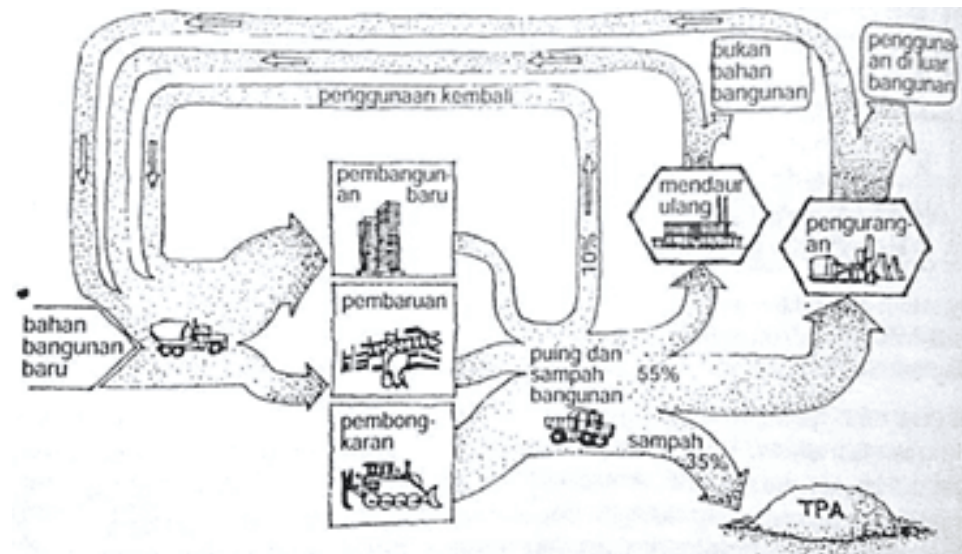

Gambar 1. Penerapan Arsitektur Ekologis dalam Peredaran Bahan Bangunan Sumber: Frick, H., 2007

Dasar ekologi terdiri dari komunitas (biosonos) dan kawasan alam (biotop). Komunitas dan kawasan alam memiliki hubungan timbal balik dan membentuk suatu sistem yang menciptakan suatu kestabilan atau keseimbangan tertentu. Ekosistem pada umumnya terdiri dari 4 komponen dasar, yaitu lingkungan abiotik, organisme produsen, organisme konsumen, organisme perombak. Lingkungan abiotik terdiri atas tanah, iklim, dan air. Tanah merupakan media yang mengandung unsur-unsur hara, memiliki kapasitas untuk menahan air, dan mengandung sifat kimia seperti nilai pH. Iklim mengandung energi, suhu, kelembaban, angin, dan kandungan gas/partikel. Sedangkan air memiliki kandungan- kandungan mineral yang dibutuhkan oleh makhluk hidup. Organisme produsen pada umumnya memiliki klorofil yang berguna membentuk bahan-bahan organik dengan menggunakan energi surya melalui proses fotosintesis. Organisme produsen adalah tumbuh-tumbuhan hijau atau bakteri-bakteri. Organisme konsumen adalah organisme yang memiliki ketergantungan hidup kepada organisme produsen atau organisme konsumen yang lain. Organisme konsumen tidak mampu membentuk bahan-bahan organik dengan menggunakan energi surya dan bahan anorganik lainnya. Organisme perombak merupakan mikroorganisme yang terdiri atas bakteri dan jamur. Organisme perombak memakan bangkai tumbuhan dan binatang, serta urin/fesesnya. Organisme perombak bersifat membusukkan dan menguraikan organisme yang telah mati, atau dengan kata lain berperan sebagai dekomposer.

\section{Isu - Krisis Pangan di Masa Depan}

Kebutuhan pangan akan terus dibutuhkan dari sekarang hingga masa depan. Hanya sedikit pengganti makanan untuk memenuhi nutrisi tubuh kita untuk hidup kedepannya, tapi tidak bisa dipungkiri pokok makanan itu sendiri tidak bisa digantikan. Keinginan manusia untuk terus 
mendapatkan makanan dengan kualitas yang terbaik dan kuantitas yang memenuhi kebutuhan hidup. Krisis pangan bisa terjadi karena ada 4 faktor penting, yaitu gaya hidup (pendapatan dan organisasi sosial menentukan tingkat konsumsi); teknologi yang digunakan menentukan sejauh mana aktivitas manusia merusak atau melestarikan lingkungan dan jumlah limbah yang terkait dengan tingkat konsumsi tertentu. Kemiskinan dapat mencegah adopsi teknologi yang lebih tepat yang dapat menghentikan atau memperlambat degradasi lingkungan. Kedua faktor ini menentukan dampaknya pada individu; ketimpangan (sebagian besar tanah dikuasai dalam jumlah besar dan kaum miskin dipaksa untuk hidup di perkebunan rakyat atau di daerahdaerah marjinal); populasi, yang bertindak sebagai pengali yang menentukan dampak total. Tingkat konsumsi atau limbah dan kemiskinan atau ketidaksetaraan, semakin banyak orang, semakin besar dampaknya terhadap lingkungan dan, pada gilirannya, semakin besar dampaknya terhadap kapasitas produksi pangan.

\section{Pertumbuhan Populasi Manusia}

Dikutip dari Food and Agricultural Organization of the United Nations (FAO) di tahun 2018, selama 10 tahun kedepan, populasi di negara industri akan bertumbuh sebanyak 56 juta orang, sedangkan di negara berkembang akan bertumbuh sebanyak 900 juta orang (United Nations Population Division, 1989; UNFPA, 1989). Pertumbuhan terbesar akan terjadi di negara-negara yang memiliki tingkat kemiskinan yang tinggi, dimana mereka yang kurang siap untuk memenuhi kebutuhan yang akan datang di masa depan. Pertumbuhan populasi yang cepat mengancam persediaan makanan di negara-negara berkembang. Lahan produksi yang baik sudah overcrowded dengan pertanian yang produksinya rendah (panen setahun sekali), mengurangi ukuran lahan pertanian dan menyebar ke daerah berkualitas rendah untuk tanaman.

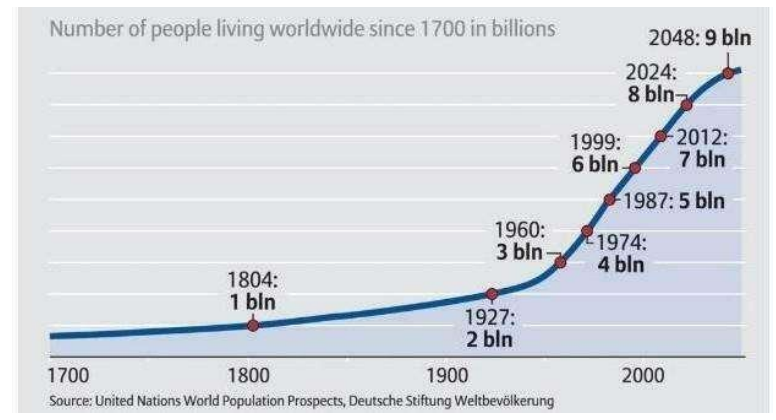

Grafik 1. Pertumbuhan Populasi Manusia

Sumber: United Nations World Population Prospects, 2017

Penanggulangan populasi yang terus meningkat sudah dilakukan di beberapa negara besar. Salah satu implementasinya adalah penggunaan lahan horizontal yang berpindah ke arah vertikal. Hunian vertikal menjadi salah satu solusi kurangnya lahan tempat tinggal di perkotaan. Dengan strategi ini, fungsi lain seperti lahan bertani juga bisa diimplementasikan ke arah vertikal dalam pemanfaatan lahan yang minim di perkotaan.

\section{Perubahan Lahan Pertanian}

Fragmentasi lahan mempengaruhi produksi pangan dan merupakan akibat langsung dari pertumbuhan penduduk yang cepat di banyak negara miskin. Alternatifnya, tanah dijual kepada pemilik tanah yang lebih kaya, membuat distribusi tanah lebih tidak merata dan menambah penciptaan sejumlah besar pekerja tak bertanah. Selain itu, pertumbuhan populasi yang cepat dapat menyebabkan praktik pertanian yang tidak tepat yang memiskinkan dan mengikis tanah; mengurangi vegetasi; penggunaan berlebihan dan bahan kimia pertanian yang tidak tepat; dan menggagalkan pengelolaan sumber daya air. Akibat dari praktik tersebut 
adalah degradasi lahan yang parah. Strategi berkelanjutan yang dibawakan oleh FAO adalah untuk memerangi erosi tanah dan kemiskinan, penggundulan hutan, penurunan hasil pertanian, dan pengelolaan air yang buruk. Pengelolaan lahan yang tepat harus diimplementasikan di daerah pedesaan untuk meningkatkan pengelolaan sumber yang baik yang mengarah kepada meningkatnya hasil panen dan menghindari degradasi lahan tani.

\section{Teknologi Bertani}

Teknologi akan membantu dalam proses produksi pangan di masa depan. Dari cara perkebunan yang berbeda, sekarang sudah ada hydroponic dan aeroponic yang dimana bisa mengurangi penggunaan lahan secara horizontal namun bisa menghasilkan jumlah yang sama. Selain 2 cara tersebut juga ada Drip System dan Deep Water Culture yang juga dikenal dengan aquaponic, yang menggunakan medianair bukan tanah.

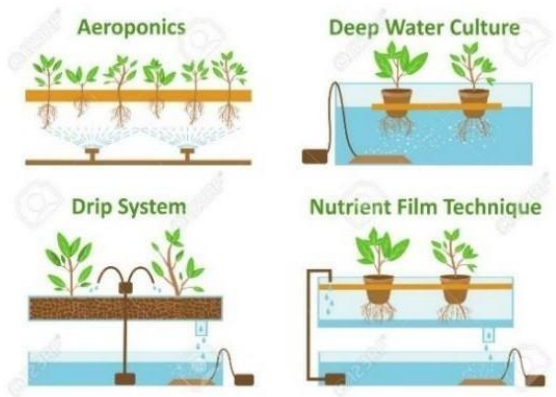

Gambar 2. Sistem Urban Farming

Sumber: hydroponic-urban-gardening.com, 2012

Sistem pertanian yang digunakan dalam hunian dengan pertanian adalah sistem aquaponic. Dengan sistem pertanian yang terintegrasi dalam keseluruhan bangunan membuat penjagaan kualitas pertanian pada hunian lebih baik.

\section{Sistem Aquaponic}

Bakteri menjadi peran utama dalam sistem pertanian ini. Siklus yang dibangun dari kotoran ikan menjadi pupuk tanaman merupakan proses yang panjang dan membutuhkan waktu. Bakteri nitrifikasi mengubah limbah ikan yang masuk ke sistem sebagai amonia, menjadi nitrat, yang merupakan pupuk untuk tanaman. Ini adalah proses dua langkah, dan dua kelompok bakteri nitrifikasi yang terpisah terlibat seperti yang ditunjukkan pada Gambar 3. Oleh karena itu sebuahpembentukan koloni bakteri yang baik adalah penting untuk sistem aquaponik baru.

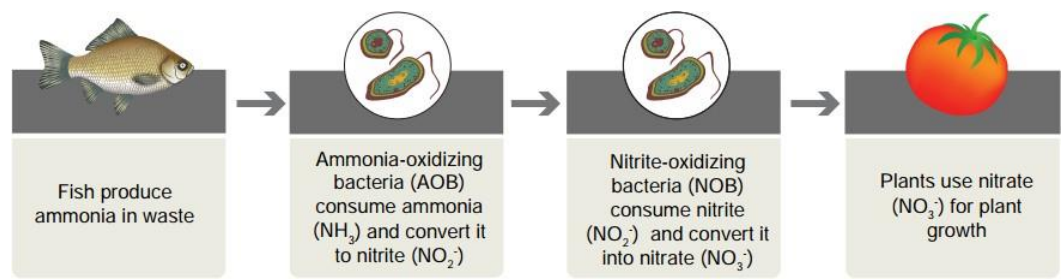

Gambar 3. Proses Nutrisi Limbah Ikan Menjadi Pupuk pada Aquaponic Sumber: Fisheries and Aquaculture Department (FI) in FAO, 2015

\section{METODE}

Pendekatan desain dan penelitian mengenal gaya dan pola distribusi yang terjadi di Jakarta. Dengan adanya data dan permasalahan yang didapat dari proses distribusi yang telah terjadi, diharapkan dapat menjadi alasan kuat dalam pemenuhan program dan fasilitas, sehingga dapat mengatasi rumusan masalah yang ada. 


\section{Past - Present}

Siklus distribusi pangan pada masa lalu sampai sekarang, dimana semua hal masih terdistribusi secara linear dari suplai yang berada di luar kota hingga konsumen yang berada di area perkotaan

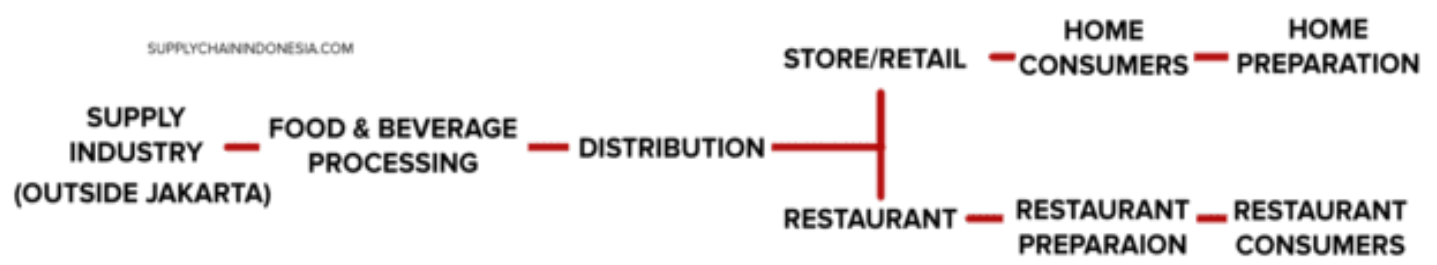

Diagram 2. Distribusi Pangan Sekarang

Sumber: Penulis, 2021

\section{Future}

Siklus distribusi pangan kedepannya diharapkan dapat menjangkau seluruh pihak yang membutuhkan distribusinya secara langsung, dan pastinya tempat produksi dan suplai tersedia di area dalam kota, sehingga proses lebih cepat, efisien dan terjamin kualitasnya

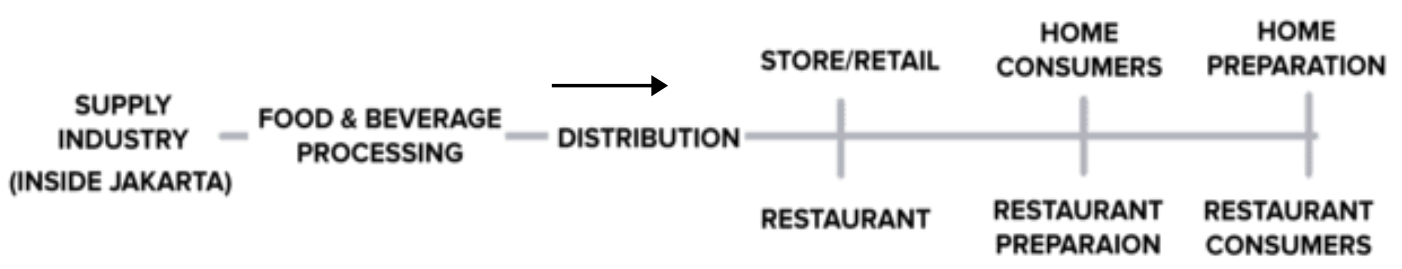

Diagram 3. Distribusi Pangan di Masa Depan

Sumber: Penulis, 2021

\section{DISKUSI DAN HASIL}

Pusat Perkebunan Vertikal Rawa Buaya di Jakarta Barat hadir sebagai lahan pertanian berbasiskan teknologi, pusat distribusi, tempat penelitian dan juga tempat berkumpul serta berbelanja bagi pengunjung. Proyek ini mendekatkan proses bertani di area perkotaan sehingga mempermudah proses bertani dan menyediakan tipologi perkebunan secara vertikal yang merupakan solusi dari terbatasnya lahan yang ada di perkotaan.

\section{Latar Belakang Pemilihan Kawasan}

Pemilihan tapak memiliki peran krusial dalam pemenuhan kebutuhan pangan daerahnya dengan minim jejak karbon, karena apabila proses distribusi membutuhkan jarak yang jauh, sama saja akan menghasilkan jejak karbon yang banyak. Tapak yang memiliki akses jalan yang dekat dengan tujuan distribusi baik itu pasar maupun wilayah hunian, akan lebih efektif kedepannya. Berikut beberapa hal yang menjadi perhatian khusus di setiap pemilihan tapak yaitu kedekatan tapak dengan target distribusi yaitu pasar dan pemukiman; Izin ketinggian bangunan, KLB yang cukup tinggi; Dekat dengan jalan besar sebagai akses kendaraan pengangkut atau distribusi. Setelah dilakukan pemetaan tapak melalui kriteria tapak diatas terpilihlah tapak yang memiliki akses jalan besar yang dekat, dapat menjamah banyak wilayah sebagai kegiatan distribusinya, terdapat beberapa pasar yang dapat menjadi target distribusi dalam radius kurang dari sepuluh kilometer. Serta memiliki perizinan yang baik dan strategis untuk dibangun proyek ini, maka terpilihlah Lokasi Rawa Buaya, Cengkareng, Jakarta Barat sebagai tapak pembangunan proyek ini. 


\section{Kawasan Rawa Buaya, Jakarta Barat}

Kawasan ini merupakan kawasan yang kebanyakan digunakan sebagai area industri, pergudangan, dan pemukiman. Serta memiliki akses transportasi yang baik. Mulai dari kendaraan roda dua, empat hingga kereta.

\section{Tapak Terpilih}

Dalam radius sepuluh kilometer, terdapat sangat banyak pasar yang dapat dijadikan target distribusi, baik di area Jakarta maupun Banten yang mencakup area Tangerang Raya (Tangerang Selatan, Kota Tangerang, Kabupaten Tangerang). Tapak yang terdapat di dekat Jalan Daan Mogot, menjadi sangat strategis karena terdapat jalan yang dapat menghubungkan daerah lainnya dengan baik.

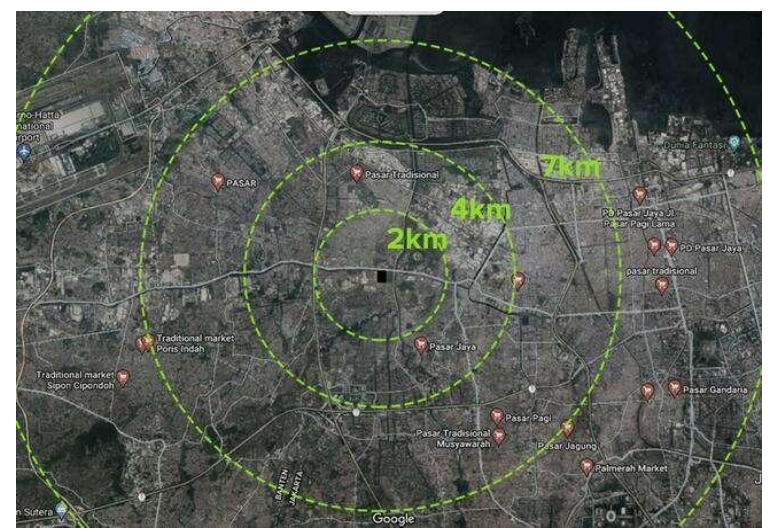

Gambar 4. Peta Radius Lokasi Pasar dari Tapak Sumber: Penulis, 2021

Dalam radius satu kilometer juga terdapat banyak pemukiman yang terdapat di sekeliling tapak. Memudahkan dan meningkatkan peluang masyarakat sekitar untuk berbelanja dan berkunjung secara mandiri ke proyek perkebunan vertikal ini.

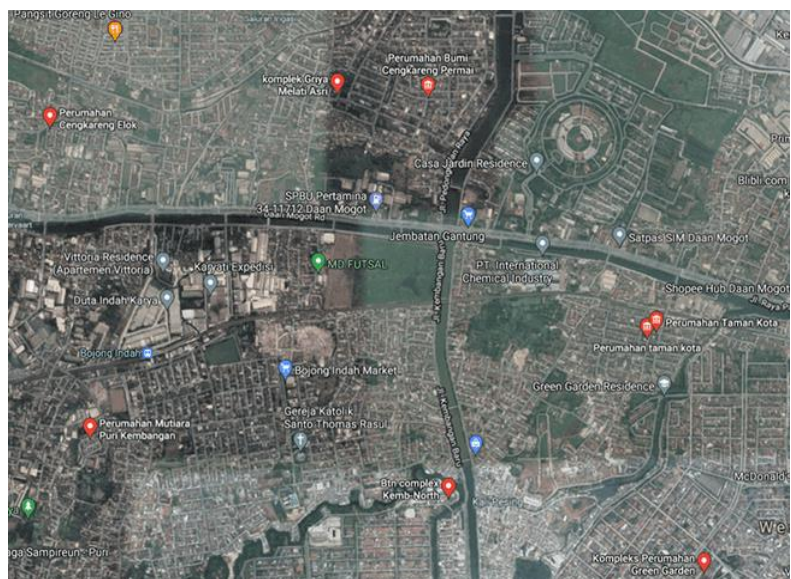

Gambar 5. Peta Pemukiman di Radius Satu Kilometer Sumber: Penulis, 2021

Berikut merupakan gambar peta fungsi lahan. Dimana lahan yang digunakan memiliki fungsi campuran, sehingga secara administrasi, legal untuk membangun perkebunan vertikal di tapak ini. Dengan luas lahan empat belas ribu meter persegi dan peraturan tapak sebagai berikut 
KDB 45\%, KLB 3.5, KB 16, KDH 30\%, KTB 55 maka batasan yang dimiliki sebesar; KDH maksimal $4.200 \mathrm{KDB} \mathrm{m}^{2}$ maksimal $6.400 \mathrm{~m}^{2}$.

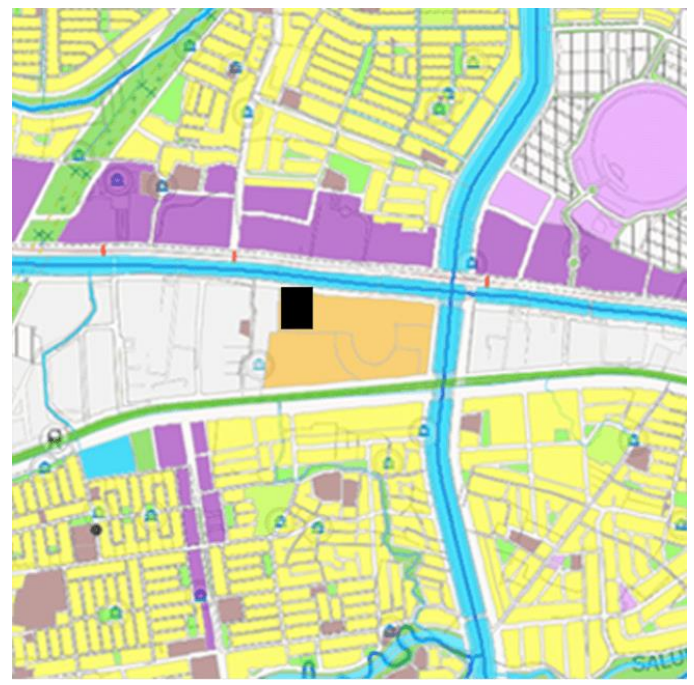

Gambar 6. Fungsi Lahan

Sumber: jakartasatu.go.id

Dilihat pada gambar 10, disekitar tapak tidak terdapat bangunan tinggi, rata-rata bangunan tinggi di radius seratus meter hanya dua hingga 3 lantai. Tapak terdapat di tanah lapang, dimana angin bergerak bebas dari arah timur menuju tapak, serta tidak terdapatnya buffer alami maupun bangunan di sekitar tapak memberikan tapak pencahayaan matahari secara maksimal di setiap waktunya.

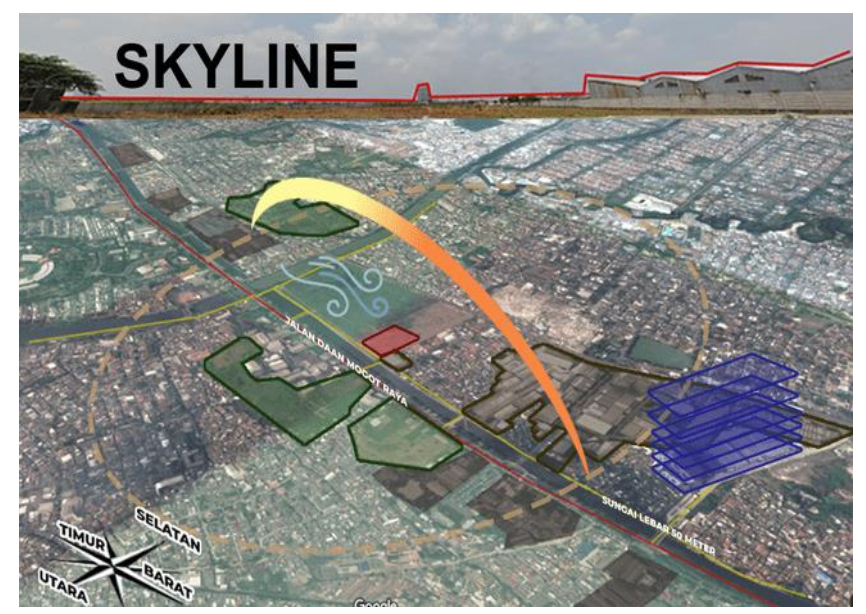

Gambar 7. Gambar Skyline dan Analisa Mikro

Sumber: Penulis, 2021

\section{Konsep}

Dalam proyek ini menggunakan konsep pendekatan bionik, dimana bentuk heksagonal diterapkan ke proyek ini. Bentuk heksagonal merupakan bentuk dasar yang sudah hadir dari alam dan ditetapkan sebagai bentuk yang paling sempurna di antara geometri lainnya. Berikut merupakan penerapan konsep heksagon setelah di implementasikan ke massa bangunan setelah disesuaikan dengan kebutuhan, baik dari zoning dan sirkulasi udara dan pencahayaan di proyek ini. 


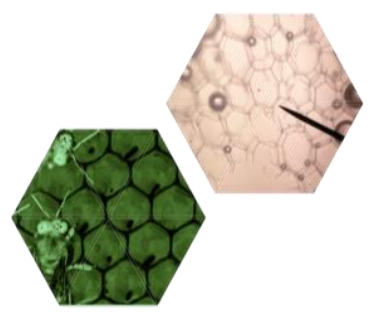

Gambar 8. Gambar Bentuk Sarang Lebah dan Sel Tumbuhan Sumber: shutterstock.com, 2015
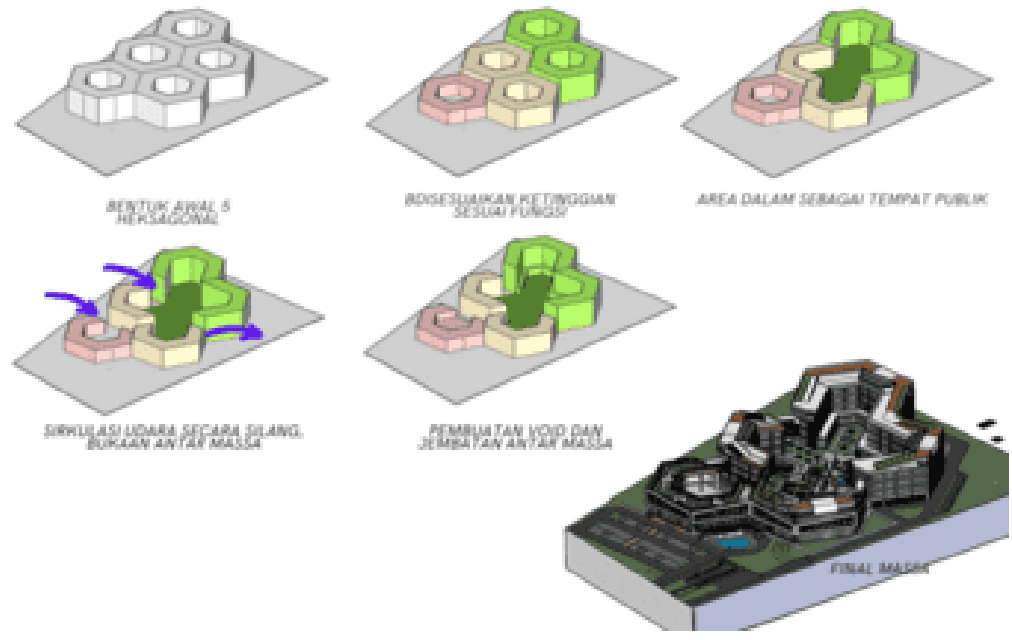

Gambar 9. Proses Pembuatan Massa

Sumber: Penulis, 2021

\section{Program}

Proyek ini menghadirkan fasilitas yang lengkap demi menunjang kegiatan yang diperlukan dalam menerapkan siklus perkebunan vertikal yang berkelanjutan. Dimana semua proses yang panjang, dipangkas dan dibuat menjadi terpusat di proyek ini. Mulai dari produksi, edukasi, distribusi, hingga penelitian, terjadi di satu tempat yang sama.

\section{Perkebunan Vertikal}

Perkebunan Vertikal sebagai sentra penumbuhan kebutuhan pangan demi memenuhi kebutuhan perkotaan. Menggunakan sistem Hidroponik sebagai media tanam yang bisa meningkatkan hasil panen jauh lebih banyak dibandingkan cara konvensional di lahan yang terbatas.

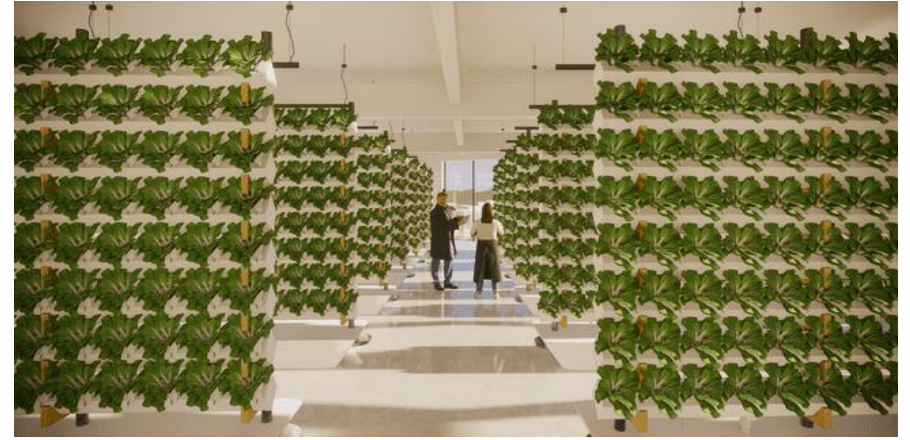

Gambar 10. Perkebunan Vertikal Hidroponik Sumber: Penulis, 2021 


\section{Pusat Distribusi}

Pusat distribusi sebagai tulang punggung dalam proses pengiriman hasil perkebunan vertikal ke seluruh pasar maupun retail yang memerlukan hasil pangan dari perkebunan vertikal ini.

\section{Pusat Edukasi dan Penelitian}

Fasilitas laboratorium dan kelas-kelas yang ada sebagai tempat edukasi dan penelitian untuk menghasilkan bibit-bibit unggulan serta meneruskan pengetahuan ke lebih banyak orang mengenai penelitian dan pentingnya peran teknologi dalam perkebunan vertikal ini.

\section{Pasar Modern}

Pasar modern sebagai tempat pendistribusian hasil perkebunan vertikal kepada masyarakat yang berhuni di sekitar tapak maupun masyarakat umum lainnya. Tempat distribusi yang sama dengan tempat produksinya, memastikan kesegaran daripada produk pangan tersebut.

\section{Sistem Hidroponik Pada Perkebunan Vertikal}

Air dari Water Treatment Plant dipompa keseluruh bangunan termasuk area perkebunan vertikal. Dimana air akan dikontrol dari ruang panel sistem ke unit-unit hidroponik yang ada pada bangunan. Air ditampung lalu diberikan nutrisi sebagai pemenuhan zat hara pada media hidroponik yang ada. Air sisa proses hidroponik yang terbuang bisa digunakan kembali setelah melalui proses filtrasi dari WTP yang tersedia.

\section{KESIMPULAN DAN SARAN}

\section{Kesimpulan}

Pusat Perkebunan Vertikal Rawa Buaya ini hadir menjadi sebuah perubahan yang lebih baik untuk masa depan, dimana dari proyek ini dapat mempermudah akses kebutuhan pangan kota, tanpa perlu bergantung kepada daerah lainnya. Pada dasarnya perkebunan vertikal adalah sebuah bentuk adaptasi dan pemenuhan kebutuhan yang semakin tinggi dari hari ke hari. Perkebunan vertikal ini terbukti efektif selain dari banyaknya panen yang di dapat. Namun juga membuat efisien dari energi dan waktu yang diperlukan dalam sebuah proses distribusi pangan ini sendiri. Tidak hanya permasalahan kebutuhan pangan yang tercukupi, proyek ini juga menyediakan fasilitas penelitian, wisata, edukasi dan distribusi. Diharapkan dapat menjadi perkebunan vertikal yang berkelanjutan karena dapat mendistribusikan hasilnya kepada masyarakat, retail, distributor lain agar mencakup wilayah yang lebih luas. Memberikan edukasi dan pemahaman mengenai kepentingan keberlanjutan pangan. Serta dapat menghasilkan bibit yang unggul dan terus beradaptasi dengan kebutuhan zaman. Sistem perkebunan vertikal urban yang menggunakan metode hidroponik diharapkan dapat menghasilkan kebutuhan pangan yang optimal tanpa memerlukan banyak lahan, air, tanah dan menggunakan usaha yang minim karena sudah menggunakan teknologi modern yang ada dan akan terus berkembang. Diharapkan proyek ini dapat membantu memenuhi kebutuhan pangan di daerah perkotaan khususnya Jakarta menjadi lebih baik lagi.

\section{Saran}

Dari segi arsitekturnya dapat menggunakan bentuk modular yang pasti lebih efisien dibanding dengan bentuk desain yang ada. Pemanfaatan ruang terbuka di luar bangunan dapat dimanfaatkan sebagai tempat produksi sekaligus edukasi rekreasi bagi masyarakat umum yang akan meningkatkan pengetahuan dan kesadaran lebih banyak orang mengenai isu pangan. 


\section{REFERENSI}

Bass, B, Baskaran. (2001). Evaluating Rooftop and Vertical Gardens as an Adaptation Strategy for Urban Areas.

Frick, H. (2007). Dasar-dasar Arsitektur Ekologis (pp. 1). Yogyakarta: Kanisius.

Jorgnsen, E., Sven. (2002). Integration of Ecosystem Theories: A Pattern Third Edition.

MVRDV. (2006). KM3 - Excursions of Capacities. New York: Actar Publishers

Tyler, Stuart. Fytogreen "Socio-Biophysical and Economic Benefits of Vertical Gardens: The Australian Experience".

Askew, K., (2017), Population growth 'a threat to food quality', diunduh 29 Agustus 2020, $<$ https://www.foodnavigator.com/Article/2017/11/10/Population-growth-a-threat-tofoodquality.

Chauveau, Remi, 2020, Vertical Farming: The Future of Urban Agriculture, $<$ https://medium.com/@remi.chauveau/vertical-farming-the-future-of-urban-agriculture2d317c50a50d

CREJ, 2019, Aquaponics a new idea in health care environment, $<$ https://crej.com/news/aquaponics-a-new-idea-in-health-care-environment/

EUFIC, 2015, Food production: A sustainable food supply, diunduh 28 Agustus 2020, $<$ https://www.eufic.org/en/food-production/article/food-production-3-3-asustainablefood-supply;.

Harrouk, C., 2020, Framlab Imagines Modular Vertical Urban Farms on the Streets of Brooklyn, diunduh 29 Agustus 2020, <https://www.archdaily.com/933879/framlabproposesmodular-vertical-urban-farms-in-brooklyn.

Nyawara, Brenda, Ken Yeang's Signature Tower In India, The Grass Is Truly Greener On The Higher Side, <https://www.archute.com/ken-yeang-spire-edge-tower-india/

Rosenfield, K., 2014, SPARK Proposes Vertical Farming Hybrid to House Singapore's Aging Population, diunduh 20 Februari 2021 <https://www.archdaily.com/573783/sparkproposes-vertical-farming-hybrid-to-house-singapore-s-aging-population-2.

RSG, Yeang Nakamura Lim, 2008, http://greenarki.blogspot.com/2008/11/yeang-nakamuralim.html

The World Bank, 2020, Food Security and COVID-19, diunduh 28 Februari 2021, $<$ https://www.worldbank.org/en/topic/agriculture/brief/food-security-and-covid-19; 